PRACE NAUKOWE UNIWERSYTETU EKONOMICZNEGO WE WROCLAWIU

Gospodarka przestrzenna XXI wieku.

Jakość życia w przestrzeni zurbanizowanej

ISSN 1899-3192

e-ISSN 2392-0041

\title{
Henryk Brandenburg
}

Uniwersytet Ekonomiczny w Katowicach

e-mail: henryk.brandenburg@ue.katowice.pl

\section{Gabriel Tobor}

Urząd Miasta Radzionków

e-mail: gabrielt@wp.pl

\section{PROBLEMY REWITALIZACJI OBSZARÓW ZDEGRADOWANYCH MAŁYCH MIAST NA PRZYKŁADZIE MIASTA RADZIONKÓW}

\section{PROBLEMS RELATED TO THE REVITALIZATION OF DEGRADED AREAS OF SMALL TOWNS ILLUSTRATED ON THE EXAMPLE OF RADZIONKÓW}

DOI: $10.15611 /$ pn.2018.502.01

JEL Classification: H11, H21

Streszczenie: Otoczenie przedsiębiorstw staje się coraz bardziej ewolucyjne, skraca się okres używalności wyrobów, w wyniku realizacji projektów innowacyjnych pojawiają się nowe produkty, często lepiej zaspokajające wymagania klientów, a produkowane mniejszym kosztem i proponowane za niższą cenę. Zmiany w otoczeniu mają również duży wpływ na działania samorządów lokalnych. Miasta stanowią dzisiaj jednostki zdolne do stanowienia o swojej przyszłości, ponieważ w dużo mniejszym stopniu niż w przeszłości są podległe władzom i decyzjom centralnym. Przekazywane są im nie tylko obowiązki zaspokajania bieżących potrzeb społecznych, ale również prawa decydowania o kierunkach lokalnego rozwoju gospodarczego. W artykule, po prezentacji miasta Radzionków i zmian, które nastąpiły w jego otoczeniu w ostatnim okresie, przedstawiono program rewitalizacji jego obszarów zdegradowanych i analizę jego zawartości w kontekście proponowanych rozwiązań potencjalnych problemów rewitalizacji obszarów zdegradowanych, które mogą być wykorzystane w innych miastach.

Słowa kluczowe: rozwój lokalny, rozwój zrównoważony, rewitalizacja obszarów zdegradowanych.

Summary: The surroundings of enterprises are becoming more and more evolutionary, the life of products is shortening, and as a consequence of the implementation of innovative projects new products, which often satisfy customers' requirements in a better way and which are produced at a lower cost and offered at a lower price, appear on the market. Changes of the surroundings have also a great impact on the decisions made by local self-governments. Nowadays, towns are units capable of deciding on their own future because they are, to 
a lesser extent than in the past, subject to central authorities and decisions. Not only are they given the responsibility to satisfy current social needs but also the rights to decide on the directions of local economic development. After presenting Radzionków and changes which have recently taken place in its surroundings, the article presents the programme of revitalization of its degraded areas as well as the analysis of the content of the programme in the context of the proposed solutions to potential problems related to the revitalization of degraded areas which may be applied in other towns.

Keywords: local development, sustainable development, revitalization of degraded areas.

\section{Wstęp}

Otoczenie przedsiębiorstw staje się coraz bardziej ewolucyjne, skraca się okres używalności wyrobów, w wyniku realizacji projektów innowacyjnych pojawiają się nowe produkty, często lepiej zaspokajające wymagania klientów, a produkowane mniejszym kosztem i proponowane za niższą cenę. Ostra konkurencja często prowadzi do prawdziwej wojny gospodarczej między przedsiębiorstwami [Brandenburg 2010, s. 7]. Zdaniem takich autorów, jak M. Joly i J.-L. Muller, „w tym jakże trudnym kontekście przeżyją jedynie przedsiębiorstwa reaktywne, przewidujące, to znaczy te, które utworzą u siebie środki słuchania otoczenia, będą zdolne zinterpretować najmniejsze sygnały nowego zapotrzebowania, uruchomią wszystkie środki, aby je zrealizować przed innymi" [Joly, Muller 1994, s. XV]. Miasto ma wiele cech wspólnych z przedsiębiorstwem wielobranżowym.W porównaniu z przedsiębiorstwem przypadek miasta jest jednak dużo bardziej skomplikowany. Przeznaczenie i warunki realizacji strategii lokalnego rozwoju są odmienne. Po pierwsze występuje podwójność efektu końcowego. Władze lokalne muszą zadowalać oczekiwania mieszkańców (zasady demokracji), ale kontrolować również stopień osiągnięcia celów własnych, bez których miasto nie może istnieć. Dla urzędu miejskiego miasto jest więc w tym samym czasie podmiotem i zasobami [Noisette, Vallerugo 1996, s. 80]. Pojęcie strategii i marketingu występuje również w dziedzinie zarządzania rozwojem lokalnym, jest jednak zupełnie odmienne od strategii i marketingu przemysłowego. O ile w przypadku projektów przedsiębiorstwa przed rozpoczęciem budowy można z góry opracować jego strategię i dostosować do niej rozwiązania techniczne i organizacyjne, o tyle projekty lokalnego rozwoju gospodarczego muszą być realizowane w konkretnej rzeczywistości (miasta przecież niejednokrotnie istnieją od wielu wieków). Szczególnie ma to znaczenie w regionach wymagających głębokiej restrukturyzacji przemysłowej, gospodarczej, społecznej, takich jak Górny Śląsk [Brandenburg 2010, s. 85]. Wprawdzie zachodzi również konkurencja między miastami, ale czy miasto może marzyć o zniknięciu swego konkurenta? Konkurencja ta musi być uwzględniona w zarządzaniu publicznym, ale nie można jej upodabniać do współzawodnictwa między przedsiębiorstwami. Radni nie mogą sobie gratulować, 
że jedne tereny (dzielnice) umierają, kiedy inne rozkwitają [Brandenburg 2016, s. 221]. Ponadto w przypadku miast na podejmowane decyzje nie wpływają jedynie zmiany w otoczeniu, ale również zmiany zachodzące wewnątrz miasta (restrukturyzacja i rekonwersja lokalnej tkanki gospodarczej, powstawanie terenów poprzemysłowych itp.). Należ również uwzględniać aspekt polityczny wyboru kierunków rozwoju lokalnego. Zdaniem J.J. Paryska „rozwój społeczno-gospodarczy pojmowany jest bardziej w kategoriach jakościowych nieźli ilościowych" [Parysek 1997, s. 52]. Na konieczność uwzględnienia opinii społecznej przy wyborze projektu publicznego do realizacji zwracają uwagę P. Noisette i F. Vallerugo, według których:

- kręgosłup projektu rozwoju lokalnego jest dynamiczny i niematerialny, a przede wszystkim ludzki,

- jego celem jest w mniejszym stopniu realizacja niż efekty [Noisette, Vallerugo 1996, s. 63].

Miasta stanowią dzisiaj jednostki zdolne do stanowienia o swojej przyszłości, ponieważ w dużo mniejszym stopniu niż w przeszłości są podległe władzom i decyzjom centralnym. Przekazywane są im nie tylko obowiązki zaspokajania bieżących potrzeb społecznych, ale również prawa decydowania o kierunkach lokalnego rozwoju gospodarczego [Brandenburg 2011, s. 11]. Miasto, podobnie jak przedsiębiorstwo, może, a nawet powinno przeprowadzić analizę swoich mocnych i słabych stron, szans i zagrożeń. Na podstawie wyników tej analizy należy opracować strategię wizerunku miasta i podjąć odpowiednie działania marketingowe mające na celu jego rozpropagowanie [Brandenburg 1998, s. 117]. Oczywiście strategia ta powinna być w miarę potrzeb aktualizowana.

W dalszej części artykułu, po krótkiej prezentacji miasta Radzionków, przedstawiono zmiany, jakie nastąpiły w ostatnich latach zarówno w otoczeniu, jak i wewnątrz miasta, będące przyczyną podjęcia przez władze samorządowe Radzionkowa decyzji o opracowaniu programu rewitalizacji obszarów zdegradowanych. W końcowej części zaprezentowano sam program rewitalizacji oraz analizę jego zawartości w kontekście proponowanych rozwiązań potencjalnych problemów rewitalizacji obszarów zdegradowanych, które mogą być wykorzystane w innych miastach.

\section{Miasto Radzionków}

Miasto Radzionków, położone na północnym krańcu Górnośląskiego Okręgu Przemysłowego, jest miastem małym. Liczba ludności w ostatnich latach maleje, obecnie kształtuje się na poziomie poniżej 17000 mieszkańców. Radzionków przestrzennie jest miastem zwartym, jego długość wynosi ponad $6,5 \mathrm{~km}$, a zagospodarowany jest na trzy jednorodne obszary funkcjonalne: zespół miejski, zespół ogrodniczy oraz zespół usługowo-przemysłowy. Zespół miejski położony jest centralnie i obejmuje zabudowę mieszkaniową i usługową wraz z przyległymi terenami otwartymi. W 1951 r. Radzionków uzyskał prawa miejskie. Nastąpiła wówczas szybka urbani- 
zacja: wybudowano Dom Kultury (oficjalnie oddany do użytku w 1966 r.), basen wraz z obiektami rekreacyjnymi, powstało też liceum ogólnokształcące do dziś będące ważną placówką edukacyjną gminy. W 1975 r. Radzionków został włączony do Bytomia. Z dniem 1 stycznia 1998, na podstawie Rozporządzenia Rady Ministrów z dnia 2 września 1997 r. w sprawie utworzenia gmin, przejęcia zadań i kompetencji oraz nadania statusu miasta w województwach katowickim i siedleckim [Rozporządzenie Rady Ministrów z dnia 2 września 1997 r. ...], odzyskał samodzielność. Radzionków sąsiaduje bezpośrednio z gminami: Bytom, Piekary Śląskie, Świerklaniec i Tarnowskie Góry. Wszystkie te gminy weszły w skład Metropolii Śląsko-Zagłębiowskiej. Związek metropolitarny zaczął działać od 1 lipca 2017 roku (zdaniem autorów artykułu fakt utworzenia metropolii Silesia może mieć kolosalne znaczenie dla dalszego rozwoju miasta).

W strukturze użytkowania gruntów Radzionkowa dominują tereny zabudowy mieszkaniowej (36\%). Wysoki udział powierzchni zagospodarowanej miasta łączy się z takimi funkcjami użytkowania jego obszaru, jak: tereny użytkowane rolniczo (19\%), tereny zieleni i wód (18\%) oraz tereny zabudowy usługowej (17\%). W strukturze użytkowania gruntów miasta niewielki jest natomiast udział terenów przeznaczonych pod funkcje produkcyjne, stanowiący zaledwie $2 \%$.

W Radzionkowie można zaobserwować trendy dotyczące zmian demograficznych, dotykające większość miast na terenie województwa śląskiego, polegające na zmniejszeniu liczby mieszkańców. Liczba mieszkańców Radzionkowa wynosiła 17420 w roku 2002, 17141 w roku 2012, 17025 w roku 2015, 16960 w roku 2016, a obecnie wynosi 16458 . Mimo spadku liczby ludności potencjał przedsiębiorczości, mierzony liczbą osób fizycznych prowadzących działalność gospodarczą, w przypadku Radzionkowa w latach 2002-2012 wykazuje tendencję wzrostową. Liczba tego rodzaju firm wzrosła o 7\%: z 1179 do 1263 (74 firmy na 1000 mieszkańców). W tym samym okresie w powiecie tarnogórskim wzrost liczby firm prowadzonych przez osoby fizyczne był dwukrotnie większy i ukształtował się na poziomie $14 \%$ (77 firm na 1000 mieszkańców), podczas gdy w całym województwie śląskim tendencja wzrostowa była zdecydowanie słabsza, co dało wskaźnik wynoszący 3\% (73 firmy na 1000 mieszkańców) [Strategia rozwoju miasta Radzionków na lata 2014-2025...]. Do największych firm na terenie Radzionkowa można zaliczyć: Kanlux - branża elektryczna i oświetleniowa, TanQuid Polska - branża paliwowa, Logtech - branża informatyki i automatyki, Ragor - branża metalowa, HAM - branża przetwórstwa mięsnego i hurtu spożywczego, Norman - branża odzieżowa. Potencjał miasta obecnie kształtują również jednostki posiadające funkcje regionalne, są to: Centrum Dokumentacji Deportacji Górnoślązaków do ZSRR w 1945 r., Regionalna Stacja Edukacji Ekologicznej, Śląski Ogród Botaniczny, Centrum Kultury Karolinka, MOSIR Radzionków z parkiem Księża Góra.

Do ważnych obiektów o oddziaływaniu ponadlokalnym należy również zaliczyć prywatne Muzeum Chleba, odwiedzane roczne przez kilkadziesiąt tysięcy osób. 


\section{Przyczyny opracowania Programu rewitalizacji obszarów zdegradowanych miasta Radzionków}

\subsection{Zmiany wewnętrzne}

Przemiany gospodarcze na Śląsku, związane z transformacją ustrojową w Polsce po 1989 r., również miały wpływ na sytuację gospodarczą i społeczną Radzionkowa. Wśród najważniejszych przyczyn negatywnych oddziaływań tychże zmian można wymienić:

1. Zamknięcie kopalni KWK Powstańców Śląskich w 1996 r.

2. Degradację terenu parku Księża Góra.

3. Degradację terenu po byłym PGR w centralnej części miasta.

Zamknięcie kopalni w Radzionkowie miało zdecydowane największy wpływ na sytuację gospodarczą i społeczną [Tobor 2003, s. 625-635]. Wśród mieszkańców nagle wzrosła liczba osób bezrobotnych, spadły dochody tej społeczności oraz pojawiło się wiele niekorzystnych zjawisk społecznych - absolwenci szkół zawodowych zostali bez pracy, odnotowano dużą liczbę byłych górników w wieku 40-50 lat przebywających na urlopach pomostowych. W miejscu kopalni zaczęły od roku 2001 powstawać nowe zakłady pracy. Zatrudniały one jednak relatywnie niską liczbę pracowników, nieporównywalną z liczbą pracujących wcześniej w kopalni. Zamknięcie kopalni miało też wpływ na likwidację szkoły górniczej i ograniczyło nabór do technikum mechaniczno-elektrycznego. W efekcie obydwa kierunki kształcenia zostały zlikwidowane. Zamknięto też oddział Tarnogórskich Zakładów Mechanizacji Górnictwa TAGOR. W efekcie w części miasta zamieszkanej głównie przez rodziny napływowe byłych górników nasiliły się negatywne zjawiska społeczne związane $\mathrm{z}$ patologią $\mathrm{w}$ rodzinie i z alkoholizmem. Prowadziły one również do degeneracji przestrzeni publicznej i substancji mieszkaniowej.

Kolejne przyczyny zmian - degradacja terenu parku Księża Góra oraz terenu po byłym PGR w centralnej części miasta - miały ujemy wpływ na zagospodarowanie przestrzeni publicznej [Tobor 2011, s. 108-123]. Park Księża Góra został zagospodarowany na cele rekreacyjno-sportowe w okresie międzywojennym XIX wieku, w latach 60. został zmodernizowany, odnowiony, powstał również kompleks basenów. Od lat 70. do końca wieku następowała stopniowa degradacja przestrzeni oraz urządzeń. Wiązało się to również ze wzrostem przestępczości na tym terenie. Pięknie położony teren, na wysokości 352 m n.p.m., dominujący nad obszarem Radzionkowa i Piekar Śląskich, został całkowicie zaniedbany.

Kolejne negatywne oddziaływanie na ład przestrzenny w mieście miała degeneracja terenu po byłym PGR. Teren ten, o powierzchni 2,4 ha, jest usytuowany w centralnej części miasta, w sąsiedztwie Centrum Kultury, trzech placówek szkolnych, przedszkola, ośrodka dla dzieci niepełnosprawnych oraz pawilonu handlowego. Obszar wokół byłego PGR-u wyróżnia się znaczną aktywnością gospodarczą w kategorii usług oraz aktywnością społeczną związaną z funkcjonującymi tam pla- 
cówkami; jest to typowy centralny obszar miasta realizujący jego podstawowe funkcje. Jednak dokładnie w środku tego obszaru funkcjonalnego położony jest teren byłego PGR, ze resztkami starych stodół i warsztatów. Po likwidacji PGR-u w latach 80. teren przeszedł w ręce prywatne. W roku 2007 gmina Radzionków zakupiła ten teren z zamiarem budowy rynku miasta. Część budynków została rozebrana w roku 2013, a pozostałe cztery budynki objęto ochroną konserwatorską, mimo ich zużycia w ponad 90\%. Dopiero w marcu 2017 r. gmina uzyskała, po kolejnym odwołaniu się do Ministra Kultury, zgodę na rozbiórkę pozostałych obiektów. Gmina ma dzisiaj Master Plan dla tego terenu i aplikuje o środki unijne na jego zagospodarowanie.

Wśród czynników wewnętrznych należy wymienić uwarunkowania rynku pracy, którego dane są niekorzystne w stosunku do bezpośredniego otoczenia. Stopa bezrobocia w Radzionkowie wynosiła w 2015 roku 8,8\% (10,6\% wśród kobiet i 7,2\% wśród mężczyzn) i była wyższa od stopy bezrobocia rejestrowanego dla województwa śląskiego 8,2\%, gdzie średnia dla całej Polski wynosiła 9,7\%. Wśród aktywnych zawodowo mieszkańców Radzionkowa 2500 osób wyjeżdża do pracy do innych miast, a 1464 pracujących przyjeżdża do pracy spoza gminy, tak więc saldo przyjazdów i wyjazdów do pracy wynosi -1036. Dane te stanowią o niskim potencjale gospodarczym względem sąsiednich miast.

\subsection{Zmiany w otoczeniu}

Procesy rozwoju miast od czasu wstąpienia Polski do Unii Europejskiej są oparte w znacznej mierze na środkach unijnych. W poprzednich okresach programowania wiele miast korzystało przede wszystkim ze środków na inwestycje infrastrukturalne. Aktualny okres programowania 2014-2020 charakteryzuje się przesunięciem ciężaru działań na procesy społeczne. Pojawienie się środków przeznaczonych na rewitalizację miast uruchomiło wiele działań przygotowawczych ze strony gmin, aby uzyskać możliwość wykorzystania tychże środków. W przypadku Radzionkowa zaistniała możliwość skorzystania z dwóch źródeł finansowania. Są to: OSI - obszary strategicznej interwencji, które wskazane zostały w Krajowej strategii rozwoju regionalnego 2010-2020, są finansowane w ramach Regionalnego programu operacyjnego województwa śląskiego na lata 2014-2020 (lokacja środków w tym zakresie dla Radzionkowa wynosi 20 mln zł), oraz ZIT-y, które wskazane są w Strategii zintegrowanych inwestycji terytorialnych subregionu centralnego województwa śląskiego na lata 2014-2020, a finansowane w ramach Regionalnego programu operacyjnego województwa śląskiego na lata 2014-2020. W ramach tej alokacji na rewitalizację terenu „Były PGR” przeznaczono $7 \mathrm{mln}$ zł.

Zmiany w otoczeniu (w sąsiadujących gminach) nie miały wpływu na decyzję o opracowaniu i wdrożeniu programu rewitalizacji. Celem programu nie jest zwiększenie konkurencyjności w stosunku do innych gmin, lecz poprawa warunków mieszkaniowych i jakości przestrzeni publicznej w mieście. Program zawężony jest do obszarów zdegradowanych. Jego realizacja ma wpływ na rozwój całego miasta, 
jednak nie dotyczy działań konkurencyjnych w regionie. Wynika to również z nastawienia obecnych władz na procesy integracji i kooperacji w ramach funkcjonowania powstającego Górnośląskiego Związku Metropolitarnego.

\section{Program rewitalizacji}

Gminny program rewitalizacji (GPR) dla gminy Radzionków, przyjęty w marcu 2017 r. [Uchwała Rady Miasta Radzionków nr XXXII/266/2017...], jest drugim tego typu dokumentem opracowanym w Radzionkowie. W roku 2005 Rada Miasta przyjęła Lokalny program rewitalizacji wybranych obszarów miejskich gminy Radzionków [Lokalny program rewitalizacji wybranych obszarów miejskich...]. W okresie ponad 10 lat nastąpiły jednak zmiany uniemożliwiające wykorzystanie tego programu. Ponadto, aby aplikować o środki zewnętrzne, gmina Radzionków zmuszona była zastosować procedurę i wymogi wynikające z ustawy o rewitalizacji z października 2015 r. [Ustawa z dnia 9 października 2015 r. ...]. Należy zatem podkreślić, że bezpośrednią przyczyną przystąpienia do opracowania gminnego programu rewitalizacji była możliwość absorpcji środków zewnętrznych na zadania, których koszt przekraczał możliwości budżetowe gminy ${ }^{1}$.

\subsection{Założenia programu ${ }^{2}$}

Przeprowadzona przez Pracownię Ewaluacji, Edukacji i Ekspertyz Społecznych 3E analiza całego miasta oraz diagnoza podobszarów rewitalizacji wykazała koncentrację negatywnych zjawisk społecznych oraz przestrzenno-funkcjonalnych i technicznych na podobszarach „Rojca” i „Były PGR”. Działania w obszarze części miasta „Rojca” finansowane będą w ramach tzw. obszarów strategicznej interwencji. Natomiast rewitalizacja drugiego wskazanego w planie terenu „Były PGR” finansowana będzie z środków przeznaczonych na zintegrowane inwestycje terytorialne.

Podobszar 1 ma charakter mieszkaniowego, robotniczego osiedla. Obserwowane tam zjawiska to przede wszystkim ubożenie części społeczeństwa i pogarszanie się jego kondycji życiowej, a także starzenie się społeczeństwa i depopulacja. Podobszar „Były PGR” zlokalizowany jest w centrum osiedla domów wielorodzinnych, a zarazem w centrum miasta. Ze względu na to, że Radzionków jest niedużym miastem, funkcjonalność obu tych obszarów i stosunkowo niewielka odległość między nimi wskazuje na spójną, tożsamą wizję rewitalizacji dla obu tych podobszarów [Gminny program rewitalizacji... 2017]. Aby zrealizować program rewitalizacji

${ }^{1} \mathrm{~W}$ związku $\mathrm{z}$ tym, że program ten był pisany pod kątem pozyskania środków unijnych (środki budżetowe gminy nie są wystarczające, aby wykonać nawet podstawowe projekty twarde), realizacja programu jest zakładana w okresie programowania 2014-2020 plus 3 lata, czyli do roku 2023.

${ }^{2}$ Intencją autorów artykułu nie jest cytowanie całego programu rewitalizacji gminy Radzionków opracowanego przez Pracownię Ewaluacji, Edukacji i Ekspertyz Społecznych 3E, a jedynie prezentacja jego podstawowych założeń. 
tych obszarów, w programie określono cele, takie jak [Gminny program rewitalizacji... 2017, s. 69]:

1. Poprawa jakości społecznego funkcjonowania mieszkańców:

1.1. Rozwiązywanie problemów społecznych.

1.2. Zapewnienie wsparcia dla dzieci, młodzieży i seniorów.

1.3. Rozwijanie zainteresowań i aktywności społecznej mieszkańców.

1.4. Wsparcie integracji społecznej mieszkańców.

1.5. Profilaktyka zdrowotna.

2. Zapewnienie lepszych warunków bytowych mieszkańcom:

2.1. Poprawa jakości mieszkań.

2.2. Stworzenie (wydzielenie, zagospodarowanie, zaadaptowanie) miejsc aktywności społecznej i zawodowej mieszkańców.

3. Rozwój zawodowy mieszkańców:

3.1. Zmniejszanie poziomu bezrobocia i pobudzanie aktywności zawodowej mieszkańców.

3.2. Wsparcie aktywności przedsiębiorców ukierunkowanej na tworzenie nowych miejsc pracy.

4. Poprawa jakości przestrzeni publicznej miasta:

4.1. Tworzenie miejsc rekreacji i aktywnego spędzania wolnego czasu dla osób w różnym wieku.

4.2. Zagospodarowanie przestrzeni publicznej w sposób estetyczny, przyjazny dla mieszkańców.

4.3. Monitoring.

W ramach pierwszego celu zidentyfikowano następujące potrzeby: działalność społeczna na rzecz osób wykluczonych społecznie, zagospodarowanie czasu wolnego dzieci i młodzieży, poprawa jakości zdrowia. W ramach drugiego celu uznano, że konieczne jest przeprowadzenie remontu budynków mieszkalnych. W ramach trzeciego celu wskazano na konieczność wsparcia przedsiębiorczości oraz aktywizacji zawodowej. W ramach czwartego celu wskazano na konieczność zagospodarowania przestrzeni publicznej oraz wykorzystanie potencjału przestrzeni byłego PGR.

$\mathrm{W}$ dalszej części programu rewitalizacji w formie tabelarycznej przedstawiono wykaz przedsięwzięć rewitalizacyjnych, zgodnie z art. 15 ust. 1 pkt 5lit.a Ustawy o rewitalizacji [Ustawa z dnia 9 października 2015 r. ...], planowane podstawowe przedsięwzięcia rewitalizacyjne wraz z ich opisami zawierającymi w odniesieniu do każdego przedsięwzięcia nazwę i wskazanie podmiotów je realizujących, zakres wykonywanych zadań, lokalizację, szacowaną wartość, prognozowane rezultaty wraz ze sposobem ich oceny w odniesieniu do celów rewitalizacji [Gminny program rewitalizacji... 2017, s. 70]. 


\subsection{Analiza programu ${ }^{3}$}

Analizując zaprezentowane w poprzednim podpunkcie podstawowe cele programu rewitalizacji obszarów zdegradowanych miasta Radzionków, nie można oprzeć się wrażeniu, że mogą one praktycznie dotyczyć wielu miast w Polsce, i to nie tylko małych. Problemy społeczne, konieczność poprawy warunków bytowych mieszkańców i ich rozwój zawodowy, zapewnienie odpowiedniej jakości przestrzeni publicznej miasta to kwestie, które dotyczą szczególnie miast postindustrialnych, a do tych należy zaliczyć Radzionków. Specyficzne wyzwanie dla tych miast stanowi osiągnięcie celu czwartego. Powstałe w wyniku rekonwersji lokalnej tkanki gospodarczej $^{4}$ (likwidacji zakładów przemysłowych) tereny poprzemysłowe bardzo często zlokalizowane są w centrach miast (na przykład teren po hucie „Kościuszko” w Chorzowie). Dotyczy to również wykorzystania potencjału przestrzeni byłego PGR, aczkolwiek problem ten dotyczy też wielu miast Aglomeracji Górnośląskiej. Z niewiadomych przyczyn niejednokrotnie PGR-y zlokalizowane były w pobliżu centrum miasta (podobnie jak w Piekarach Śląskich, gdzie PGR był zlokalizowany w pobliżu osiedla mieszkaniowego i Wojewódzkiego Szpitala Chirurgii Urazowej; aktualnie zabudowania po byłym PGR zostały zagospodarowane przez hurtownie). W przypadku Radzionkowa teren ten przeznaczony jest pod budowę rynku. Radzionków do końca XIX w. był gminą typowo wiejską. Centralnym punktem i osią przestrzeni publicznej był plac targowy, jednak w latach 70. XIX w. został on zabudowany budynkami wielorodzinnymi. Budowa rynku stwarza nowe możliwości dla jakości przestrzeni publicznej i rozwoju miasta.

Mankamentem programu jest nieuwzględnienie relacji miasta $\mathrm{z}$ jego otoczeniem. Nie można analizować silnych i słabych stron miasta, bez uwzględnienia szans i zagrożeń z otoczenia. Przecież miasto, jak każda organizacja, zależne jest od swego otoczenia, na które może wpływać, ale które również na nie oddziałuje. Miasta, które często między sobą konkurują, chociażby w celu zainteresowania potencjalnych inwestorów swoimi terenami poprzemysłowymi, powinny również współpracować. Na konieczność współpracy zwraca uwagę G. Tobor w pracy doktorskiej [Tobor 2009]. W efekcie brakuje j korelacji z analogicznym programem rewitalizacji wdrażanym w sąsiedniej gminie - Bytomiu. GPR w Bytomiu jest realizowany również w ramach obszarów strategicznej interwencji. Współdziałanie w zakresie realizacji obydwu działań powinno dotyczyć projektów społecznych kierowanych przede wszystkim do grup osób wykluczonych społecznie. Wspólne przedsięwzięcia w tym względzie umożliwiłyby lepsze wykorzystanie zasobów utworzonych ze środków OSI.

${ }^{3}$ Również w tym przypadku intencją autorów artykułu nie jest ocena krytyczna programu rewitalizacji gminy Radzionków, a jedynie analiza jego zawartości w kontekście rozwiązań potencjalnych problemów rewitalizacji obszarów zdegradowanych, które mogą być przydatne w innych miastach.

${ }^{4}$ Termin „rekonwersja” używany jest w literaturze francuskiej, definiowany jest jako całkowita zmiana, zastępowanie jednych rodzajów działalności gospodarczej innymi [Thierry 1995, , s. 14]. 


\section{Podsumowanie}

Podjęcie decyzji o konieczności opracowania gminnego programu rewitalizacji dla gminy Radzionków i jego przyjęcie przez Radę Gminy świadczy o dojrzałości władz samorządowych tego miasta. Otoczenie gminy stanowią gminy sąsiadujące, z którymi bardzo często dana gmina konkuruje. Każda gmina w swej strategii rozwoju powinna więc uwzględnić strategie gmin sąsiadujących. Nie poddając krytyce przyjętego przez Radę Miasta Radzionków programu rewitalizacji, należy jednak zauważyć, że uwzględniono w nim jedynie silne i słabe strony miasta. Mankamentem programu jest zaś nieuwzględnienie relacji miasta $\mathrm{z}$ jego otoczeniem. $\mathrm{W}$ programie nie przewidziano również alternatywnych scenariuszy związanych z ryzykiem wystąpienia określonych przeszkód, m.in. takich jak: pojawienie się nieprzewidzianych robót budowlanych związanych z remontami budynków, ograniczenie wielkości dofinansowania ze środków unijnych, problemy z pozyskaniem ostatecznych beneficjentów działań społecznych czy wycofanie się z realizacji projektów społecznych przez organizacje pozarządowe wskazane w GPR. Ponadto bardzo mogą się zmienić możliwości rewitalizacji tych obszarów z chwilą uruchomienia aglomeracji górnośląskiej, w skład której wejdzie również Radzionków.

\section{Literatura}

Brandenburg H., 1998, Projekt przemysłowy, przedsiębiorstwa, rozwoju lokalnego. Różnice i cechy wspólne, materiały konferencyjne, Konferencja Naukowa „Nowoczesność przemysłu i usług w regionie", TNOiK, PAN Oddz. w Katowicach, AE w Katowicach, Politechnika Śląska, Ustroń.

Brandenburg H., 2010, Projekty restrukturyzacyjne - planowanie i realizacja, Wydawnictwo Akademii Ekonomicznej w Katowicach, Katowice.

Brandenburg H., 2011, Zarzadzanie lokalnymi projektami rozwojowymi, wydanie III uzupełnione, Wydawnictwo Akademii Ekonomicznej w Katowicach, Katowice.

Brandenburg H., 2016, Znaczenie zarządzania ryzykiem w planowaniu projektów publicznych, Studia i Prace Wydziału Nauk Ekonomicznych i Zarządzania, nr 46/1, Gospodarka Regionalna i Międzynarodowa, tom 1, Wydawnictwo Naukowe Uniwersytetu Szczecińskiego, Szczecin.

Gminny program rewitalizacji dla gminy Radzionków, 2017, Pracownia Ewaluacji, Edukacji i Ekspertyz Społecznych 3E, Warszawa.

Joly M., Muller J.-L., 1994, De la gestion de projet au management par projet, Edition AFNOR.

Lokalny program rewitalizacji wybranych obszarów miejskich gminy Radzionków, Uchwała nr XXVII/ 184/2005 Rady Miasta Radzionków z dnia 8 lutego 2005 r.

Noisette P., Vallerugo F., 1996, Le marketing des villes. Les éditions d'organisation.

Parysek J.J., 1997, Podstawy gospodarki lokalnej, Wydawnictwo Naukowe Uniwersytetu A. Mickiewicza w Poznaniu, Poznań.

Rozporządzenie Rady Ministrów z dnia 2 września 1997 r. w sprawie utworzenia gmin, przejęcia zadań i kompetencji oraz nadania statusu miasta w województwach katowickim i siedleckim, Dz.U. 1997 nr 109, poz. 705 .

Strategia rozwoju miasta Radzionków na lata 2014-2025, Uchwała Rady Miasta Radzionków nr XLII/ 395/2014 z dnia 27 lutego 2014 r. w sprawie strategii rozwoju miasta Radzionków na lata 2014-2025 . 
Thierry D., 1995, Restructurations et Reconversions. Concepts et méthodes, Editions L'Harmattan.

Tobor G., 2003, Zagospodarowanie terenów poprzemysłowych w gminie górniczej Radzionków w latach 1998-2003, [w:] Nowoczesność przemystu i ustug - teoria i praktyka, praca zbiorowa, TNOiK, Katowice.

Tobor G., 2009, Wspótpraca międzykomunalna narzędziem wdrażania strategii rozwoju, praca doktorska, Akademia Ekonomiczna w Katowicach, Katowice.

Tobor G., 2011, Program a projekt lokalny - analiza przypadku na przykładzie zagospodarowania „Księżej Góry” w Radzionkowie, [w:] H. Brandenburg (red.), Zarzadzanie projektami lokalnymi - przykłady realizacji, Studia Ekonomiczne, Zeszyty Naukowe Uniwersytetu Ekonomicznego w Katowicach, nr 75, Wydawnictwo Uniwersytetu Ekonomicznego, Katowice.

Uchwała Rady Miasta Radzionków nr XXXII/266/2017 z dnia 30.03.2017 r. w sprawie przyjęcia Gminnego Programu Rewitalizacji dla Gminy Radzionków.

Ustawa z dnia 9 października 2015 r. o rewitalizacji, Dz.U. 2015, poz. 1777.

Ustawa o związku metropolitalnym w województwie śląskim, Dz.U. z 6 kwietnia 2017 r., poz. 730. 